\title{
Index of Manuscripts
}

\section{Cambridge}

Corpus Christi College, Parker Library

- Parker MS 16 (Chronaca Majora) 185

Copenhagen

Copenhagen University, Arnamagnæan

Manuscript Collection

- AM 47 fol 226

- AM 194 8vo 203, 226-232, 235, 238, 470, 497

- AM 325 II 4to (Ágrip) 162

- AM 489 4to 235

- AM 544 4to (Hauksbók) 215, 425, 428, 435-453

- AM 567 4to 235

- AM 589 a 4to 224, 235

- AM 732b, 4to 424-425, 433, 435, 439, 443, 451-453

- AM 736 I, 4to 224, 425-427, 431, 435, 440, 443, 446-448

- AM 736 II 4to 226

Royal Library (Det konglige bilbliotek)

- GKS 1005 (Flateyjarbók) 226, 232

The Hague

National Library of the Netherlands (Koninklijke Bibliotheek)
London

British Library

- BL Add MS 49598 64, 359

- BL MS Harley 612262

Oslo

Norwegian State Archives (Riksarkivet)

- NRA lat. fragm.NBS1054-1059/NBS 343

- NRA Ms. 29211

Rome

Biblioteca Apostolica Vaticana,

- BAV MS Fondo S. Maria Maggiore 253

- BAV Ottob. lat. 90261

\section{Stockholm}

Royal Library (Kungliga biblioteket)

- Holm Perg 5226

- Holm Perg 34 4to (Landslog Magnúss Hákonarsonar) 517-518

- MS A 14261

- KB 76 F 5430 
